\title{
"What We Lost In Syria, We Had Already Lost In Palestine:" Uncovering Stories Across Generations of Palestinian Women Born in Syria
}

\author{
Mette Edith Lundsfryd Stendevad
}

\begin{abstract}
Knowledge about the stateless Palestinian population of Syria is limited, and the experiences of Palestinian women particularly remains uncovered. This paper argues that the loss of Syria as a safe home affects Palestinian woman born in Syria in several ways. The paper explores twelve constraints that bear an impact on women's lives, including female experiences of statelessness, denial of "the right of return," forced family separations and lack of access to uninterrupted family life, lack of freedom of movement, the inability to pass nationality onto children, denial of UNRWA services, lack of rights to political participation, unemployability, lack of access to protection as refugees, lack of rights to belong via citizenship, and experiences of racialisation. The structural constraints have disproportional implications with regards to the women's age, education level, marital status, maternity status, and their current place of exile. The results presented here are based on women's oral history as part of a decolonial intersectional feminist epistemology centralised in Palestine Studies. This paper illustrates a prolonged, transgenerational, and cross-continental marginalisation of Palestinian women from Syria, while also documenting their endeavours to speak up for their right to belong where they are, as well as to return to Palestine.
\end{abstract}




\section{Introduction}

Scholars and activists alike have argued that Palestinians in Syria have experienced a "unique integration" into Syrian society since $1953^{1}$ unique due to the level of civic rights such except political and citizenship rights, as rights to education, integration into the workforce, adult Palestinian men's right to own real estate and establish intellectual institutes, and for males compulsory military services. Some of those, who had arrived before 1956, had more civic rights in Syria than those who were registered later; those who arrived before 1956, for instance, were granted Syrian travel documents. Today many Palestinians from Syria miss their homes in Syria yet also describe the unique integration as a "unique form of oppression and containment." "The uniqueness of Palestinians' experiences in Syria came to a stark rupture with the outbreak of the Syrian conflict in 2011 and the vulnerabilities of the stateless population were once again targeted. Those who had inherited travel documents could flee the warzone, while those who had not, became caught in the crossfire. In June 2019, the Institute on Statelessness and Inclusion (ISI) stated that there is an urgency in acquiring and analysing knowledge on the situated, intersecting, and gendered consequences of statelessness. ${ }^{3}$ Oppression against women is found to be aggravated by statelessness and displacement, as evidenced by their unequal access to resources, gender segregation in labour markets and education systems, a gender and ethnicity pay gap, violence against women and girls, reproductive rights, health conditions, and gendered social norms. Stateless women are specifically targeted by being prohibited from passing their nationality onto their children, as well as by being denied the right to political participation and free movement. ${ }^{4}$

This paper presents a transgenerational selective analysis of stateless women's lived experiences, with a focus on structural continuous constraints and the loss of Syria of Palestinian women born in Syria ${ }^{5}$. The four generations of women interviewed in this study echo the same sentiment: despite thorough integration into the Syrian society, they have all experienced continuous constraints as stateless women. The phrase "structural continuous constraints" refers to multi-layered and interlocking forms of oppressions that are shaped by structural power mechanisms, both colonial and post-colonial. These constraints have occurred in women's lives repeatedly, and cross-generationally, in three different contexts: Palestine, Syria, and Europe. They are linked to the history of British colonial rule in mandate Palestine and to Al-Nakba.

\footnotetext{
${ }^{1}$ Laurie A. Brand "Palestinians in Syria. Politics of Integration," The Middle East Journal, 1988, Vol. 42(4), p.621-637; Nidal Bitari, "Yarmouk Refugee Camp and the Syrian Uprising," Journal of Palestine Studies, 2014, Vol. 43(1), p. 61-78.

${ }^{2}$ Conversation with Amal Wissam February 2018.

${ }^{3}$ Nina Murray, "Join the feminist revolution in work to address statelessness," Website, European Network on Statelessness, 18 July 2019, available at:

https://www.statelessness.eu/blog/ioin-feminist-revolution-work-address-statelessness [Last accessed on 22 November 2019]; Institute on Statelessness and Inclusion, "World Conference on Statelessness," The Hague, Institute on Statelessness and Inclusion, 2019, available at: https://www.institutesi.org/conference [Last accessed on 27 February 2020].

${ }^{4}$ Nira Yuval-Davis, "Women and the Biological Reproduction of "the nation"," Women's Studies International Forum, 1996, Vol. 19(1-2), p. 17-24; Suad Joseph, Gender and Citizenship in Middle Eastern States, New York, Syracuse University, 2000; Nadje Al-Ali, Secularism, Gender \& the State in the Middle East: The Egyptian Women's Movement, Cambridge, Cambridge University Press, 2000; Islah Jad, "Rereading the British Mandate in Palestine: Gender and the Urban - Rural Divide in Education," International Journal of Middle East Studies, 2007, Vol. 39, p. 338-342; Rania Maktabi, "Gender, Family law and Citizenship in Syria," Citizenship Studies, 2010, Vol. 14(5), p. 557-572.

${ }^{5}$ Throughout this paper, the different terms used to describe the participants - "Palestinian from Syria," "Palestinian of Syria," "Palestinian Syrian," and "Palestinian born in Syria" - reflect the preferred use of each participant.

${ }^{6} \mathrm{Al}-\mathrm{Nakba}$ is an Arabic term that means "the catastrophe". It refers to the catastrophe of war, displacement, eviction, and occupation of Palestine.
} 
Between 1947 and 1949, some 800,000 people were evicted from Palestine. The war razed 531 villages to the ground and depopulated 11 towns. ${ }^{7}$ The vast majority of exiled Palestinians were forced to live in refugee camps of Lebanon, Syria, and Jordan. ${ }^{8}$ Approximately $80 \%$ of the displaced population to Syria were women and children. ${ }^{9}$ At least 82,000 Palestinian people fled Palestine to the newly established nation-state of Syria. The rights that the Palestinians had lost in Palestine during the British occupation and the escape from Palestine between 1917 and 1948, were transferred into exile, where they became third range inhabitants of the host country, enjoying fewer rights than Syrian nationals. This subsequently marginalised the indigenous Palestinian women ${ }^{10}$ as they were denied equal access to education, equal access to women-oriented healthcare, political participation, and employment in Palestine and beyond. ${ }^{11}$

Gendered aspects of the occupation and Al-Nakba have been revisited by a number of feminist and decolonial scholars. ${ }^{12}$ They argue that $A l-N a k b a$ is not a single dated event -15 May 1948 - but a collection of crucial events that began prior to 1948. Several historians trace Al-Nakba back to three settler colonial historical events and plans for population transfer: the 1882 Zionist summit; ${ }^{13}$ the 1914 British-French Sykes-Picot Agreement; and the 1917 Balfour Declaration, which led to the British occupation of Palestine and the incremental settler colonialism. ${ }^{14}$ Furthermore, experiences of $\mathrm{Al}$-Nakba continue to seep into the present through prolonged displacement, statelessness, and rejection of the United Nations' (UN) stipulated "right of return of all displaced persons and their descendants to their homeland in Palestine." ${ }^{15} \mathrm{Al}-\mathrm{Nakba}$ is thus past, present, and future, all at once.

\footnotetext{
${ }^{7}$ Nur Masalha, Expulsion of the Palestinians. The concept of Transfer in Zionist Political Thought, 1882-1948, Beirut, Institute for Palestine Studies, 1992; Nafez Nassal, The Palestinian Exodus from Galilee, 1948, Beirut, Institute for Palestine Studies, 1978; Rosemary Sayigh, “Women's Nakba Stories: Between Being and Knowing, " In Ahmed Sa'di and Lila Abu-Lughod (eds.), Nakba: Palestine, 1948, and Claims of Memory, New York, Columbia University Press, 2007, p. 135-160; Rosemary Sayigh, "The Nakba's Exclusion from the "Trauma Genre"," Journal of Palestine Studies, 2013, Vol. 43(1), p. 51-60; Ahmed Sa'di and Lila Abu-Lughod, NAKBA: Palestine, 1948, and the Claims of Memory, New York, Columbia University Press, 2007; Anaheed Al-Hardan, "Remembering the Catastrophe: Uprooted Histories and the Grandchildren of the Nakba," PhD Dissertation, Dublin, University of Dublin, 2011.

${ }^{8}$ Elise G. Young, Gender and Nation Building in the Middle East: The Political Economy of Health from Mandate Palestine to Refugee Camps in Jordan, London, Bloomsbury Academic, 2012.

${ }^{9}$ Hamad Said Al-Mawed, The Palestinian Refugees In Syria Their Past, Present and Future, Ottawa, International Development Research Centre, 1999; Rosemary Sayigh, Palestinians: From Peasants to Revolutionaries, London, Zed Books Ltd, 1979.

${ }^{10}$ Islah Jad, op.cit., 2007; Nadera Shalhoub-Kevorkian, "Palestinian Women and the Politics of Invisibility: Towards a Feminist Methodology," Peace Prints: South Asian Journal of Peace building, 2010, Vol. 3(1), p.1-21; Nahla Abdo, Women in Israel Race, Gender and Citizenship, London, Zed Books Ltd, 2011; Nahla Abdo and Nur Masalha, An Oral History of the Palestinian Nakba, London, Zed Books Ltd, 2018.

${ }^{11}$ Elise G. Young, "From Data to Doctor. Health, Gender, and the Race for Control of Knowledge-Making in Mandatory Palestine," Thamyris, 1997, Vol. 4 (2), p.347-58; Islah Jad, op.cit., 2007.

${ }^{12}$ Rosemary Sayigh, "Nakba Silencing and the Challenge of Palestinian Oral History," In Nahla Abdo and Nur Masalha (eds.), An Oral History of the Palestinian Nakba, London, Zed Books, 2018, p.114-135; Elise G. Young, Keepers of the History: Women and the Israeli Palestinian Conflict, New York, Teachers College Press, 1992; Annelies Moors, "On Appearance and Disappearance. Representing Women in Palestine under the British Mandate," Thamyris, 1996, Vol. 3(2), p.279-310; Ellen L. Fleischmann, The Nation and Its "New" Women: The Palestinian Women's Movement 1920-1948, Los Angeles, University of California Press, 2003; Islah Jad, op.cit., 2007; Nahla Abdo and Nur Masalha, op.cit., 2018; Nur Masalha, The Palestine Nakba: Decolonising History, Narrating the Subaltern, Reclaiming Memory, London, Zed Books Ltd, 2012; Anaheed Al-Hardan, op.cit., 2011; Anaheed Al-Hardan, Palestinians in Syria: Nakba Memories of Shattered Communities, Columbia, Columbia University Press, 2016; Ruba Salih, "Bodies That Walk, Bodies That Talk, Bodies That Love: Palestinian Women Refugees, Affectivity, and the Politics of the Ordinary," Antipode, 2016, Vol. 49, p.742-760.

${ }^{13}$ Nur Masalha, op.cit., 1992; Nur Masalha, op.cit., 2012.

${ }^{14}$ Nur Masalha, op.cit., 2012; Lorenzo Veracini, Settler Colonialism: A Theoretical Overview, Hampshire, Palgrave Macmillan, 2010.

${ }^{15}$ Susan M. Akram, "Myths and Realities of the Palestinian Refugee Problem: Reframing the Right of Return” In Michael Lynk, Michael Dumper, Susan Akram, lain Scobbie (eds.), International Law and the Israeli-Palestinian Conflict. A Right-Based Approach to Middle East Peace, New York, Routledge, 2011, p.183-198.
} 
This paper explores how structural constraints intersect with the categories of age, education, employment, marital status, maternity status, and place of living. ${ }^{16}$ The constraints that affect women's daily lives in Syria and the grief resulting from the loss of Syria are paramount to understanding the complexity of these women's lived experiences. This is why the analysis conducted here includes constraints in addition to experiences of loss. Though the participants have reached safe havens, they continue to experience aggravated oppression, whether in Europe or in war-torn Syria, which is why speaking of Syria "mithl maa kaanat [as it was]" tends to be sentimentalised in light of this loss. Jescala Al-Homsia, ${ }^{17}$ a young female participant displaced from Al-Aidin camp in Homs (Syria) to Denmark, eloquently articulates the continuousness of complex displacements and gendered statelessness:

"My grandmother was Palestinian from Palestine, made stateless and a refugee; my mother is a stateless Palestinian refugee from Syria; I am a stateless Palestinian refugee from Syria in Denmark. I can never imagine calling myself a Palestinian from Denmark. I wonder what my daughter will be."

This paper is based on my doctoral dissertation (to be completed in 2021), which provides a thorough understanding of cross-generational continuities, and an in-depth analysis of the ongoing war in Syria, seen through the lens of the women of the Palestinian communities in Syria. This is achieved through recorded oral histories with 21 Palestinian women from four generations, and conversations with 29 additional individuals - all originally Palestinians but born in Syria. Moreover, five participants, which I refer to as "public participants," were interviewed for background information. Three public participants are represented in this paper as informants with significant background knowledge: Leila Al-Shami, a Syrian-British author and human rights activist; Hady Ibrahim, a Palestinian activist and freelance journalist born in Syria, and Buthaina Shaheen, a Syrian-Palestinian activist and the director of the Syrian Cultural Institute in Denmark. These public participants' in-depth knowledge about the topics investigated and the different research fields helped to fill various gaps in the existing literature on the history of Palestinians from Syria.

The oral history participants identify as cis women from low-income families, born into three different Palestinian communities in Syria, all of which have been targets of sieges, bombardments, artillery attacks, and starvation since 2012. The women were born and raised during four different historical junctions: the period in time that immediately followed Al-Nakba; the period that is marked by the Palestinians' resistance to the occupation of Palestine after 1967; the Lebanese Civil War (1975-1990), when Palestinians from Syria fought alongside either the Palestinians in Lebanon or the Syrian army in the PFLP-GC; and the beginning of the 21st century, which saw a change in the Syrian regime, with Bashar al-Assad becoming president.

The four generations are named and defined by the participants via the political events that have unfolded the past 70 years. ${ }^{19}$ This paper investigates twelve continuous constraints

\footnotetext{
16 "Place of living" is a sociological term that denotes the place in which a person is physically present, even if he/she does not have a permanent or legal residency in this specific place, meaning that they might be residing there temporarily. Anthropologist Julie Peteet used the term "place of living" to describe the places in which Palestinians in Lebanon live, e.g. a refugee camp, a temporary home, or a territory where you do not have any rights, but in which you still exist. The term is used here instead of "country of residence." See: Julie Peteet, Landscape of Hope and Despair: Palestinian Refugee Camps, Philadelphia, University of Pennsylvania Press, 2005.

${ }^{17}$ Participants have been anonymised by self-chosen pseudonyms.

${ }^{18}$ Reflexive notes and conversation with Jescala Al-Homsia, January 25 Feb 2018.

${ }^{19}$ The conceptualisation of generations will be unpacked in the section "Renewing Women's Oral History."
} 
faced by the participants: female experiences of statelessness and the denial of "the right of return" to Palestine; forced family separations at borders/checkpoints; the inability to pass down nationality to children; access to political participation across continents; employment; access to UN services; access to the human right of uninterrupted family life, ${ }^{20}$ experiences of racialisation affected by the intersections of age, education, employment, marital status, maternity status, and place of living.

The socio-historical experiences of Palestinian women from Syria living in exile in Europe, or internally displaced in Syria, remain under-documented. Some scholars have, however, highlighted the lived experiences of Palestinian communities in Syria. ${ }^{21}$ Most recently, $\mathrm{Al}-\mathrm{Hardan}$ recorded the recollections of Al-Nakba of three generations before the war broke out in Syria, with a specific focus on generations one and three $;{ }^{22}$ Gabiam created a unique ethnography of the Neirab and Ein Al-Tal camps; ${ }^{23}$ and Shaheen documented the experiences of Palestinian minors from the Yarmouk camp. ${ }^{24}$ Finally, Ziadah analysed the struggles and hardship of Palestinians from Syria as they have been on the move towards Europe, and the challenges within European asylum systems. ${ }^{25}$

This paper consists of three main sections. The first section outlines the methodology used in this paper. The second section presents an analysis of gendered statelessness and women's rights in Syria, focusing on the structural constraints and their implications on the contemporary experiences of Palestinian women in Syria. The third and final section draws the attention to the different combinations of loss, which participants across generations highlight in their oral histories. Each generation of Palestinian women experiences loss in a different way; the categories of age, level of education, marital status, maternity status, and the place of living, shape the means through which memories of what was lost connects the participants to Palestine. The loss of Syria as a safe home marks a new period for the participants, which started with a call for freedom and dignity, that remains unheard.

\section{Renewing Women's Oral History}

This research unfolds based on women's oral history as a tool to document the history of a recent past. ${ }^{26}$ The recordings of their oral histories are collected through numerous

\footnotetext{
${ }^{20}$ As defined by Article 8 of the European Convention on Human Rights (1953), the ability of families to live habitually together as an entity without interference from state authorities.

${ }^{21}$ Laurie A. Brand, op.cit., 1988; Hamad Said Al-Mawed, op.cit., 1999; Åge A. Tiltnes, "Palestinian Refugees in Syria: Human Capital, Economic Resources and Living Conditions", Borggata, FAFO, 2006, available at: https://www.fafo.no/index.php/en/publications/fafo-reports/item/palestinian-refugees-in-syria-human-capital-esconomic -resources-and-living-conditions [Last accessed on 27 February 2020]; Anaheed Al-Hardan, op.cit., 2011;Anaheed Al-Hardan, "Decolonizing Research on Palestinians: Towards Critical Epistemologies and Research Practices," Qualitative Inquiry, 2013, Vol. 20(1), p.61-71; Anaheed Al-Hardan, op.cit., 2016; Salah Hassan, "Palestinians in Syria and the Syrian Uprising," Doha, Arab Center for Research and Policy Studies, 11 October 2012, available at: https://www.dohainstitute.org/en/lists/ACRPS-PDFDocumentLibrary/Palestinians in Syria and the Syrian Uprising.pdf [last accessed 27 February 2020]; Nell Gabiam, The Politics of Suffering: Syria's Palestinian Refugee Camps, Bloomington, Indiana University Press, 2016; Buthaina Shaheen, "Yarmouk Minors: Their Situation and Displacement... Their Agency through Cultural Forms, Psychosocial Activities and through Daily Life Actions," British Journal of Middle Eastern Studies, November 2018, p.1-16; Rafeef Ziadah, "Journeys of Dispossession: Palestinian Refugees from Syria Confronting Fortress Europe, " Website, Darkmatter, 2016, available at: http://www.darkmatter101.org/site/2016/05/16/iourneys-of-dispossession-palestinian-refugees-from-syria-confronting-fo rtress-europe/ [Last accessed on 27 February 2020].

${ }^{22}$ Anaheed Al-Hardan, op.cit., 2011; Anaheed Al-Hardan, op.cit., 2016.

${ }^{23}$ Nell Gabiam, op.cit., 2016.

${ }^{24}$ Buthaina Shaheen, op.cit., 2018.

${ }^{25}$ Rafeef Ziadah, op.cit., 2016.

${ }^{26}$ Kristina Minister "A Feminist Frame for the Oral History Interview," In Sherna B. Gluck and Daphne Patai (eds.), Women's Words, New York, Routledge, 1991, p. 27-42; Ronald J. Grele and Studs Terkel, Envelopes of Sound: The Art of Oral History, London, Praeger, 1991; Susan H. Armitage, "The Stages of Women's Oral History," In Donald A. Ritchie (eds.), The Oxford
} 
one-on-one recordings of conversations that took place between January 2018 and January 2020. In addition, "speaking back sessions" were developed: ${ }^{27}$ participants were re-invited to listen to their own recordings, reinterpret them, and decide which themes are relevant for further publication, in order to create a space of shared authority. ${ }^{28}$ The intention was to make a conscious effort to think otherwise and write with people rather than about people, while asking how this research makes a difference. ${ }^{29}$ In practice, this means that a longitudinal aspect is built into the research design, which maintains the connection between the researcher and the participants, and helps to document fluidity and changes within the narratives of the participants. As such, the societal changes that affect the participants' daily lives are also documented, such as discussions around "repartition and deportations of Syrian refugees to Syria," a debate that took sail during the field research.

The recordings and observations were collected across a scattered and porous field in Denmark, Germany, Lebanon, and Syria. The lived experiences recounted by the women are told as a mix of linear, circular, and repetitive events, a process that merges, pauses, and rebuilds memories. They are documented via oral history recordings, discussed and reorganised with and by the women themselves, in cooperation with the author, through several processes. These include informal meetings, informal hangouts, ${ }^{30}$ recording sessions, online conversations, sharing of pictures, items, and official oral history recordings, interviews, and post-recording sessions called speaking back sessions. Divided into two groups, seven participants are represented. Four main oral history participants are presented here through pseudonyms they allocated to themselves: Teta Loubia, Amal Wissam, the Pharmacist, and Jescala Al-Homsia. These women are of Palestinian heritage and were born in Syria. They reside in Syria's Palestinian communities Yarmouk camp (Damascus), Khan Es-Sheih camp (south of Damascus), and Al-Aidin camp (Homs). Moreover, three "public participants" contribute to the research with their knowledge on the field(s) through their positions as human rights activists, authors, and intellectual activists.

The oral history participants come from low-income backgrounds and range from 22 to 70 years of age. Recordings were made in colloquial Arabic and were subsequently translated by the author into English. The different generations are conceptualised through the labels used by the participants to describe the one they believe they belong to and they were divided accordingly. The first generation studied in this paper, is born in Palestine or Syria between 1947 and 1953, and is known amongst Palestinians as "the Generation of the Nakba" [jil al-nakba]. ${ }^{31}$ The second generation, born between 1969 and 1985, is known amongst Palestinians as "the Generation of the Revolution" [jīl al-thawra] named after the Revolution of $1965 \cdot{ }^{32}$ The third generation, born between 1985 and 1995, is referred to by participants as

Handbook of Oral History, Oxford, Oxford University Press, 2012, p.169-185; Lynn Abrams, Oral History Theory, New York, Routledge, 2010; Anne Valke and Leslie Brown, Leslie Living with Jim Crow: African American Women and Memories of the Segregated South, New York, Palgrave Macmillan, 2010; Sherna Gluck, “What's so Special about Women? Women's Oral History." Frontiers:A Journal of Women Studies, 1977, Vol. 2(2), p.3-17.

${ }^{27}$ Bell Hooks, "CHOOSING THE MARGIN AS A SPACE OF RADICAL OPENNESS." Framework: The Journal Of Cinema and Media, 1989, Vol.36, p.15-23.

${ }^{28}$ Anne Valk and Leslie Brown, op.cit., 2010; Anne Valk et al., "Engaging Communities and Classrooms: Lessons from the Fox Point Oral History Project," The Oral History Review, 2011, Vol. 38 (1), p. 136-57; Michael Frisch, A Shared Authority. Essays on Craft and Meaning of Oral and Public History, New York, State University of New York Press, 1990.

${ }^{29}$ Ghassan Hage, "Towards a Critical Arab Social Science," Website, Critical Legal Thinking, 8 April 2013, available at: http://criticallegalthinking.com/2013/04/08/towards-a-critical-arab-social-science/ [Last accessed on 27 February 2020].

${ }^{30}$ Janelle L. Dance, Mary Hermes and Gutierrez Rochelle, "More Like Jazz Than Classical: Reciprocal Interactions Among Researchers and Respondents," Harvard Education Review, 2010, Vol. 80(3), p. 327-352.

${ }^{31}$ The youngest generation born in Palestine in the beginning of the 20th century has been named "the Generation of Palestine" [j II filasțin]. See: Rosemary Sayegh, op.cit., 1979, p.58; Rosemary Sayegh, op.cit., 2018.

${ }^{32}$ Rosemary Sayegh, op.cit., 1979, p.58; Rosemary Sayegh, Too Many Enemies. The Palestinian Experience in Lebanon, London, Zed Books Ltd, 1994. 
"the Generation which fuelled the Uprisings and lost Syria" [jil wuqud al-thawra wa faqd süria $]$. Finally, the fourth generation, born between 1995-2000, is known as "the Generation of the Struggle and the Return... to Palestine" [jūl al-kafāh wu al- 'awda... ila filasțin].

\section{Stateless, while Woman, and Refugee}

The legal status of "stateless" was created as a legal label for "Palestine refugees" world-wide between 1948 and $1951 .{ }^{33}$ The refugee status legalises a lack of political and civic rights such as equal access to education, employment, health services, and aid throughout the United Nations Relief and Works Agency for Palestine Refugees in the Near East (UNRWA) mandate area. The temporariness of these statuses for Palestinians has endured almost perpetually, calcifying into "statelessness." The same is true of Palestinians in Syria, even though Syrian nationals who hold Syrian citizenship had a larger extent of pro forma participatory citizenship than women in neighbouring countries in the region, ${ }^{34}$ and opposed to Palestinians in Lebanon, ${ }^{35}$ and modern-day Israel, ${ }^{36}$ who have fewer political rights than their female counterparts in the region.

Nevertheless, Palestinians in Syria were granted some formal rights, such as employment and education, though they do not have the right to vote or run for office. They can organise themselves through workers' unions, but they cannot do so independently from the government, the way that Syrian citizens can. ${ }^{37}$ Palestinian women thus experience both structural and personal limitations within the society they lived in. The greatest threat to women's political activism in Syria today, remains the Syrian regime. ${ }^{38}$ The women who participated in this study spoke of the regime's authoritarian oppression, which further deprived them of their right of freedom of speech and movement due to statelessness and gender. Amal Wissam said that "everyone who argues that Palestinians in Syria are not discriminated against, is lying. We all know this. As Palestinian women, men, and children, what we lost in Syria, we had already lost in Palestine; and we never got it back." ${ }^{39}$ She went on to describe the discrimination that women face in terms of salaries, job opportunities, and freedom of movement. When she says that "what was lost in Syria, we had already lost in Palestine," she refers to women's right to be equal citizens with equal opportunities, equal protection for their children, the ability to transfer citizenship to their children, freedom of movement, and the ability to return to Palestine and to leave Syria.

Four women in this study reveal twelf constraints that they still face following their forced escape from Syria (4-5 years ago), all of which will be elaborated on in this section. The theme - loss of Syria - echoes the experiences that are encapsulated in the title of this paper, "What we lost in Syria we had already lost in Palestine." This phrase evokes a sentiment that all participants have: the fact that Syria was a safe home for them for a significant amount of time, but that the rights which they were denied in Syria, both as women and as stateless Palestinians, were aggravated through their experiences as refugees, whether in Europe or through internal displacement in Syria. The different generations that these women belong to; their level of education and employment, their ability to learn a new language, their

\footnotetext{
${ }^{33}$ Susan M. Akaram, op.cit., 2011.

${ }^{34}$ Suad Joseph, op.cit., 2000; Susanna Ferguson, "Listening to Rights Talk in Damascus," Comparative Studies of South Asia, Africa and the Middle East, 2015, Vol. 35(3), p. 557-574.

${ }^{35}$ Rosemary Sayigh, "Palestinian Camp Women as Tellers of History,"Journal of Palestine Studies, 1998, Vol. 27(2), p. 42-58; Ruba Salih, op.cit., 2016.

${ }^{36}$ Nadera Shalhoub-Kevorkian, op.cit., 2010; Nahla Abdo, op.cit., 2011.

${ }^{37}$ Laurie A. Brand, op.cit., 1988.

${ }^{38}$ Skype Interview with Leila Al-Shami, 20 March 2018.

${ }^{39}$ Wissam, Amal, Oral History Recording, 9 March 2018, Copenhagen.
} 
country or place of living; marital status; and maternity status are all factors that affect the participants differently, and often in a disproportionate manner. Gendered statelessness is a dark cloud that impacts and obscures various aspects of women's lives. They carry the burden of statelessness (1); are denied the right of return (2); have been the target of forced family separations and been denied family unification (3); and cannot pass citizenship onto their children either because they have no legal citizenship or because they are women (4). They can only pass their statelessness. This has been the case across the four generations of women who's oral life stories have been here. It goes back even further in time, and has also been extended into the European context. Women in Denmark with citizenship, for example, can pass their citizenship onto their children, but children in Denmark born to women with refugee status and stateless status will not automatically be granted Danish citizenship. This applies to stateless children, making them equally stateless by birth unless their parents apply for citizenship, which can only be done after birth, and is not guaranteed. ${ }^{40}$

The specificities of displacement and statelessness in Syria changed the narrative of Syria as a safe home for Palestinians. During the early days of the uprising in Syria, families' freedom of movement became limited fairly quickly (5), and the country became "a world of checkpoints" overnight. ${ }^{41}$ Women on the move alone without their fathers, husbands or brothers would be detained and harassed due to a Syrian Family Law which makes it illegal for women to move without their legal male guardian i.e. there wali. ${ }^{42}$ Many women describe how they before the war could move alone, but after the escalation of violence this law was suddenly effectuated. Furthermore, Palestinians were denied access to UNRWA services (6), and upon attempting to cross the borders to Jordan, Turkey, or Lebanon, they were completely stripped from their rights (both as stateless citizens and as refugees) due to the UN "protection gap" (7). This meant that stateless Palestinian refugees staying in the UNRWA mandate area would be ineligible for UNHCR services as refugees, while also being excluded by national laws. ${ }^{43}$ Some were pushed back due to their Palestinian identity documents and were not allowed to flee the war zone. At borders/checkpoints, all women describe being discriminated against with regards to their gender, nationality, and statelessness. They were subjected to slurs, racialised as Palestinians, presumed to be sex workers, and ultimately denied access, or forcefully separated from their family members. While some of them were able to cross the border, others were pushed back. The women described clandestine border crossings where they were divided into male and female groups, and during which their young male children or grandchildren were forcefully taken from them. It was often the case that the female group would be able to cross the border, while the male group would not, resulting in the separation of mothers, daughters and grandmothers from their husbands, brothers, sons, fathers, and male friends.

As a consequence of the limitations of free movement and family separations, the women who participated in this study, regardless of their age, had all suffered from a lack of uninterrupted family life (8). This is caused by the forced separations described earlier, as well as by European host countries' denial of family reunifications. The generation of the Nakba (the first generation), is particularly vocal about this. In many cases, the elderly had either been left behind in Syria, or had travelled alone and been separated from the rest of their families. This means that grandmothers from the generation of the Nakba live by

\footnotetext{
${ }^{40}$ Anja Kublitz, "From Revolutionaries to Muslims: Liminal Becomings Across Palestinian Generations in Denmark," International Journal of Middle East Studies, 2016, Vol. 1, p. 67-86.

${ }^{41}$ Walid in: Mette Heide-Jørgensen Lundsfryd, "Speaking Back to a World of Checkpoints: Oral History as a Decolonizing Tool in the Study of Palestinian Refugees from Syria in Lebanon," Middle East Journal of Refugee Studies, 2017, Vol. 2(1), p.73-95.

${ }^{42}$ Rania Maktabi, op.cit., 2010.

${ }^{43}$ Susan M. Akram, op.cit., 2011.
} 
themselves in Syria or Europe, while their daughters and granddaughters have been reunited in a new setting. Women, in general, suffer from severe interruptions in their family lives. Their families become scattered globally. Though they used to live closely together in Syria, family members ultimately disperse across Syria, Palestine, Denmark, Germany, Sweden, Austria, Canada, and Australia. Several families had lost family members; some have passed away, and others remain as disappeared persons. Others are separated and the ability to communicate with or travel to see family members in other countries is severely restricted, due to travel bans for refugees and asylum seekers and the lack of financial resources.

These constraints lead to the lack of rights to belong as legal citizens or even as counted within national statistics (9). The structural constraints that women face in Syria are reproduced in the European context. In various European national statistics, there is insufficient documentation on the figures of stateless populations. ${ }^{44}$ The exact number of Palestinians from Syria in Europe remains unknown due to challenges in the documentation process. Over the past few years, few efforts have been made by European official institutions and statistics departments to provide a well-studied database. ${ }^{45}$ For example, it is impossible to determine the number of Palestinian women from Syria in Denmark or Germany.

According to Statistics Denmark, the central bureau on Danish statistics on in-migration, Palestinians who arrived from Syria are either registered as "stateless" or as "stateless arriving from a third country" (outside Europe), e.g. Turkey or Lebanon. This means that their historical trajectory as being "Palestinians from Syria" remains unlabelled and unregistered, and the statistics do not show that they come from Syria or Palestine, but rather, that they are "stateless". ${ }^{46}$ This affects the women and their children, should they choose to claim a legal place of belonging at a later stage.

The women who participated in this study were denied the right of political participation (10) through a denial of their right to vote, and the oldest generation talk of their mothers and grandmothers also being denied the right to vote in Palestine during the mandate and Zionist settlements. Essentially, the political voices of these women, men, and children residing in Europe continue being silenced, since they still live under stateless circumstances, with no access to political participation, whether as refugees or asylum seekers, in Europe. None of the women in this study had the right to vote in any of the countries in which they took up residence. They spoke of the harrowing effect that non-participation had on their lives. Shaheen explained: "Not being able to participate politically in a society to which I contribute so much on a daily basis, in a country in which my children are citizens, but I am not, is one of the greatest injustices."

The women belonging to the first and second generations (respectively, the generations of the Nakba and of the Revolution) find themselves in a limbo-like state of permanent temporariness, unemployment, and ostracism. They spent most of their lives in Syria, where they were doubtlessly discriminated against, at least to some degree, as stateless women. Nevertheless, it was a place in which they had a home and belonged to a community - they

\footnotetext{
${ }^{44}$ Action Group for Palestinians of Syria and The Palestinian Return Centre, "Palestinians of Syria and the Closed Doors", London, Action Group for Palestinians of Syria and The Palestinian Return Centre, 2017,p.41, available at: https://www.actionpal.org.uk/en/pdf/closeddoor2016.pdf [last accessed on 27 February 2020]; Anja Kublitz, op.cit., 2016.

${ }^{45}$ Action Group for Palestinians of Syria and The Palestinian Return Centre, op.cit., 2017, p.41.

${ }^{46}$ Email correspondence with Anna Dorthe Bracht from Statistics, Denmark, April 16 2019. When asked how many Palestinians from Syria (men, women and children) have arrived in Denmark since 2011, she responded: (translated from Danish): "Unfortunately, Statistics Denmark does not have information on Palestinians in Denmark. Most Palestinians will be included in our population statistics with the country of origin Lebanon. But unfortunately, we cannot say what proportion of Lebanese people the Palestinians make up." Also see: Anja Kublitz, op.cit., 2016.

${ }^{47}$ Interview with Buthaina Shaheen, Copenhagen, 13 February 2018.
} 
spoke the same language as the rest of society and were familiar with the local culture and societal norms. The women in exile further away from Syria report that the prolonged nature of the temporary status keeps them from living together as families and communities. Unemployability, the level of education, and the lack of political rights permeate the three eldest generations (the generations of the Nakba, of the Revolution, and the generation fueling the Uprisings) and crosscut countries, from Palestine and Syria to European territories. Unemployability (10) seems to antagonise the second generation of women the most, as they had lost their full-time jobs in Syria, thus compromising their position as co-breadwinners. As a consequence, they are either jobless, working internships, which are in fact unpaid work, or doing low-skilled work that includes cleaning and organising the storage facilities of supermarkets. In Europe, much like in Syria, the second generation of women recounted being denied the ability to stay in their line of work because they were both Palestinian and women. Their foremothers were denied work as midwives and nurses in Palestine during the British occupation; today, they are being denied work within their specialised fields as refugees in Denmark and Germany. ${ }^{48}$

In contrast, the younger generation of women, now settled in Europe, have been given access to formal education and have successfully passed national language tests and high school exams; those of them who are now settled in Denmark and Germany have learned their host country's language, and passed preparatory courses for university. As such, they venture into a new period of their lives, metaphorically pregnant with hope, while their mothers remain unemployed, struggle to learn a new language, and grapple with severe depression. These women's grandmothers live in different countries and find themselves cut off from their new society in relation to language, cultural dissimilarities, and (un)employment. The eldest generation of women from Syria, who have little or no education, are perceived by their host countries as being unable to contribute to their new setting and are often left to their devices as a consequence. The women who participated in this study reported that the fathers in their families used to be the family's co-breadwinners in Syria. Currently, however, these fathers hold different positions. Many are severely ill, unemployed, have become unable to speak due to post-traumatic stress disorder or injuries to the brain, have been captured by the Syrian regime, or suffer in other ways leaving their wives and older children to become the family's main breadwinners. Members of the younger generation, who have become adept at new languages and skills, are now students, and have to work up to three side jobs to be able to provide for their families. Meanwhile, the mothers feel destitute and ostracized. Many of them search for any job they can get, but feel that they have been misguided by their host country (Shaheen 2020), landing jobs as dishwashers, storage workers in supermarkets, and cleaning ladies, all under the flag of "language training" and "internships that will benefit integration." 49

Finally, the women found it crucial to include their experiences of racialisation in exile (12). Though they all express gratitude to their host country and the local population, the women pinpointed several instances during which they experienced racism. They perceive statelessness and the denial of return to Palestine as racial structural laws that keep them away from their homeland and from citizenship rights in their new host country, while also giving way for further ostracization and stereotyping. They describe, for instance, being physically and verbally abused because of their headscarves, ${ }^{50}$ the men in their families being targets for arrests, and their narratives being deemed unworthy. The women of the fourth

\footnotetext{
${ }^{48}$ Elige G. Young, op.cit., 2012.

${ }^{49}$ Buthaina Shaheen, "Ambivalences of Citizenship: Syrians with Refugee Status Responding to Ambivalences of Citizenship in Denmark,"Journal of Refugee Studies, 2020, fez107.

${ }^{50}$ Not all women in this study wear a hijab (headscarf).
} 
generation maintained that, in Europe, they are often treated as if they were "ignorant" and "backwards" because of their nationality or accents. These experiences differ from the ones they had had in Syria, and from the memories recounted to them by the Palestinian women of the first generation. In Syria, however, the women indicated that Palestinians are generally perceived as "intelligent" and "well educated," while contrastingly, in Europe, they are perceived as "thugs," "ignorant," backwards," "dirty," "submissive," and "promiscuous." As a participant said, "in Syria I am Palestinian, in Denmark I am Syrian”. Such experiences affect their daily lives and tasks, such as walking on the street, sitting in a classroom, or taking the bus.

These constraints affect all women, regardless of their age, marital status, maternity status, and level of education. Still, not everyone experiences unemployability; mothers of the second generation are affected the most. Being denied the freedom of movement, and uninterrupted family life, political participation, and civic rights impacts all the participants. It is striking, therefore, that they all find that they are subjected to no less than twelve different continuous structural constraints (as outlined in this section), which have not been resolved as they have moved to a "safe place" in more "democratic" countries, such as Denmark and Germany, where they have now resided 5 years. Their statelessness feeds into every part of their everyday lives, whether in Europe or in Syria.

\section{Palestinian Women from Syria Speak of Loss}

The specificities of what each individual, who once lived in Syria, had lost, is seldomly public knowledge. The women who participated in this study had lost their homes, and the trauma they had been subjected to made them lose some of their memories.$^{51}$ One lost a son, another lost her friends, and all of them lost the feeling of freedom. One young woman described how she never felt like a refugee until she arrived in Denmark. "Before that, I never knew what it was like, even though I was born a stateless refugee in Syria," she said. Much more than could be captured here has been lost and remains unbeknownst to anyone apart from those who have experienced this loss.

All participants said that they had lost the right to be connected and unified as families and as communities. They have repeatedly and agonizingly used the expression rāhat sūryā ["Syria is lost" or "Syria has gone away"], whether they are reflecting on their memories of Syria, speculating about the future, where to go next, or where they risk being deported to. At the same time, participants revealed that displacement had allowed them to redefine themselves, leading to "liberating experiences" or "improved circumstances," through new avenues of education and new skills learned. They have come to have a strong sense of independence; yet these newfound freedoms do not eclipse the affection they still feel towards Syria. They, at once, value the new experiences and miss the life they had in Syria.

In Europe, the second generation of women who participated in this study lead a more domestic life due to unemployment and to the fact that they now live in more isolation. Work-life balance is radically different from the way it was before. This is due to limited access to education, language barriers, mental and physical health issues, post-traumatic stress disorder symptoms, mourning both the loss of Syria and the death of family members and friends, and feeling of confinement after having been detained by different authorities.$^{{ }^{2}}$

\footnotetext{
${ }^{51}$ Didier Fassin and Richard Recthman, The Empire of Trauma: An Inquiry into the Condition of Victimhood, New Jersey, Princeton University Press, 2009; Veena Das, “The Act of Witnessing: Violence, Poisonous Knowledge, and Subjectivity” In Mamphela Ramphele, Arthur Kleinman, Pamela Reynolds, and Veena Das (eds.), Violence and Subjectivity, Berkeley, University of California Press, 2000, p.215-225; Rosemary Sayigh, op.cit., 2013.

${ }^{52}$ Maya Abyad, "Imprisoned By The Regime, And Ostracised By Society. Consequences of detention for Syrian women," Website, Syria Untold, 2019, available at:
} 
More optimism awaits the fourth generation of women, who have had better access to education, and have thus expanded their networks and language skills at a much faster rate than their mothers and grandmothers. For the fourth generation of women, the future holds more promise with regards to both employment and relationships, romantic or otherwise.

As was mentioned previously, all participants expressed a heartfelt melancholy at the "loss of Syria." In order to document this feeling of loss, which is experienced by the different generations of Palestinian women born in Syria, researchers need to understand what the participants had in Syria. In the following section, I will present Teta Loubia from the first generation (of the Nakba) and Amal Wissam from the second generation (of the Revolution). Teta Loubia ${ }^{53}$ is a 65 -year-old woman who used to live in the Yarmouk camp near Damascus who had been separated from the rest of her family when they attempted to leave Syria together in 2013. She was born in Syria shortly after her mother's arrival to the country; she had left Haifa for Syria during the Nakba of 1948, and was already pregnant then. In 2013, Teta Loubia was separated from the other members of her family - as they were fleeing the Yarmouk camp near Al-Tadamon - by Syrian soldiers, who had installed spontaneous checkpoints all over the country. She managed to get to the Lebanese-Syrian border, where she was allowed to cross to Lebanon. The rest of her family, however, was pushed back by the Lebanese General Security at Al-Masnaa border crossing. ${ }^{54}$ Teta Loubia could not expound on what she had in Syria without shedding more light on what she had lost. She said that she had one daughter and one grandson in Syria, another daughter in Denmark, two sons in Germany, and her only granddaughter was traveling to Denmark on her own. Teta Loubia was stuck in Lebanon, unable to go back to Syria, and did not have the means to fly out of Lebanon. Her 24-days tourist visa in Lebanon was long over. Like the majority of Syrians and Palestinians from Syria in Lebanon, she was without legal status. ${ }^{55}$ I met Teta Loubia again in 2016 when she had finally made it to Germany, three years after being separated from the rest of her family.

"My husband died of cancer in Syria in 2011, before the war. Allah yarhamuhu [may God protect him]. He did not live to see the destruction and forced separation we have had to endure. Sometimes I think it's better that way; it would have broken his heart. We used to all live very close to one another in the same building. We had a home. Now, I have a daughter in Syria, a daughter in Denmark, and two sons in Germany, and we will never be united in the same place for Eid al-fitr [Festival of Breaking the Fast] again. We see each other on the phone [video call] when we have internet and electricity, and that's it. I can't read or write, so I only communicate with them using pictures, flowers and hearts emojis, and voice messages." ${ }^{56}$

Teta Lubia went on to explain that the loss of her home in Syria affects all aspects of her life today. The new place of living is neither a home nor a safe place. She explained, "I sleep, eat and shower here, but it is not a home". Her adult children used to be a big part of her house but now they are scattered across Europe and Syria. She further explained that she had been found ineligible to take German language classes because she was "too old" to work and this

https://syriauntold.com/2019/10/07/imprisoned-by-the-regime-and-ostracised-by-society/?fbclid=|wAR03V5ql mEWQ4Tp sTsiKWXOEsGiQTpfi3tsDRNH7hFaUMs4y9Sp AcNg A [last accessed 27 February 2020]

${ }^{53}$ Teta is a common phrase used to refer to one's grandmother in colloquial Arabic. Loubia is the name of her village in Palestine and a nickname she gave her granddaughter. Teta Loubia is a pseudonym chosen by the participant .

${ }^{54}$ Lebanese border patrols officially closed the borders for Palestinians from Syria in May 2014. Since 2013, Amnesty International and Human Rights Watch have reported push backs of Palestinians from Syria fleeing the war. See: Mette Heide-Jørgensen Lundsfryd, op.cit., 2017.

${ }^{55}$ Ibid.

${ }^{56}$ Oral History Recording, Teta Loubia, March 2018. 
prevented her from building real connections with the new local community and new friendships. In Syria, her Yarmouk apartment was a hub for the entire extended family. Teta Lubia was preoccupied with domestic work, taking care of her grandchildren and other children in the hara (neighbourhood). She also helped to run errands for her daughter's shop, which was placed just under her apartment in the three stories building. "I used to be like the rawda (daycare) for the children in Yarmouk, so everyone knew me there, here in Germany, no one recognises me in the neighbourhood," she said. In Syrian, she also used to feel at home because her late husband's grave was nearby, in the burial ground of Yarmouk Camp. Today, her children are alive, but she lost her husband and a grandson, and their graves are in Syria. The graves symbolise the loss of a relative, a part of one's family, and collective history, all at once.

Amal Wissam, ${ }^{57}$ a 48 -year-old woman belonging to the second generation of stateless Palestinians, first left Syria for Denmark in 2012. Her grandparents had left the coastal town of Jaffa in Palestine for Syria during the Nakba of 1948. She reminisced about her home in Syria, showing me pictures of her house on her phone; she had been renting a newly refurbished apartment, with a kitchen full of plastic flowers and marble, and a veranda full of natural orange flowers. For Amal, the loss of Syria is equated with the loss of a real home. She explained that Denmark is like a beit amen [a safe house], but not a beit haqīqi [a real home]. She misses the feeling of being recognised on the street and knowing every area and person in the neighbourhood. Amal tragically lost her teenage son during the early days of the Syrian uprisings in 2011. Mourning his death, and being forced to leave behind his grave in the Yarmouk camp, weighed heavily on her. Her life is a testament to the countless catastrophes that exist within the prolonged Nakba narratives. In the spring of 2011, the Assad regime made it possible to play the young Palestinian protesters out against their primary enemy, the Israeli army, at the Golan Heights for the commemorations of Al-Nakba Day $^{58}$ and Al-Naksa Day ${ }^{59}{ }^{60}$

"I went into my son's bedroom, shortly after he was killed on the Syrian-Palestinian border. I came across several notebooks filled with handwritten poems to and about Palestine, as though they were love letters to a secret girlfriend. He died in 2011, at the age of sixteen, while protesting for our right of return to the land we had lost in 1948. He was shot in the eye at the Golan Heights by Israeli snipers. He was buried in the Yarmouk camp in Syria. The cemetery of Yarmouk was destroyed by $D \bar{a}$ ish ${ }^{61}$ and the Syrian regime. In Denmark, I have nothing but my memories of him, and his martyr pictures on the wall. I called my sister, who is still in Damascus, and she showed me his destroyed grave."

The quote above shows both the complexity of regional conflicts and the prolonged displacement of the Palestinian population. Despite Amal's grandparents' forced expulsion from Jaffa in 1948, her son was killed by Israeli snipers in Syria 63 years later. Twelve to eighteen ${ }^{63}$ young Palestinians from the Yarmouk camp were killed that same day. Amal's son did not live to see the uprisings, the war, or his family's separation and escape. He never met his youngest sister, who was playing on the floor next to me, as his mother told me his story.

\footnotetext{
${ }^{57}$ Amal Wissam is a self-chosen pseudonym. Amal means hope in Arabic.

${ }^{58} \mathrm{Al}-\mathrm{Nakba}$ Day is the annual public commemoration of the eviction from Palestine.

${ }^{59} \mathrm{Al}-\mathrm{Naksa}$ Day is the annual public commemoration of the 1967 war and the military occupation of Palestine.

${ }^{60}$ Nidal Bitari, op.cit., 2014; Salah Hassan, op.cit., 2012; Skype interview with Leila Al-Shami, op.cit., 2018.

${ }^{61} d \bar{a}$ ish Arabic abbreviation for the Islamic State of Iraq and the Levant.

${ }^{62}$ Oral History Recording \#2 with Amal Wissam, March 2018.

${ }^{63}$ Sources give conflicting numbers, Amal Wissam and newspaper outlets say 18 while Bitari writes of twelve persons killed that day. See: Nidal Bitari, op.cit., 2014.
} 
His funeral, which took place on 6 June 2011, became the first big anti-regime protest in the Yarmouk camp, initiated by the Palestinians of Yarmouk. ${ }^{64}$ The Palestinian community was furious that the young protestors were scapegoated by the Syrian regime, and that Israeli snipers had been allowed into Syrian territory, shooting live ammunition and throwing tear gas bombs. Amal had lost both her home and her son. On her way to Denmark, Amal had lived in temporary exile in Lebanon from 2012 to 2014 in the camp of Ein El-Helweh, near Saida. Her husband travelled to Sudan by boat, and she separated from him as well as her eldest daughter until they were united in 2014 in Copenhagen. In Lebanon, Amal was pregnant and gave birth to her daughter in Ein El-Helweh. Despite the tragedy of losing her son and having to leave Syria, she managed to set up a life for her family in Denmark. She is now attending language classes, and her husband, with whom she was reunited, has a job and shares the daily chores of cooking, cleaning, and picking up their youngest daughter from nursery school.

Amal Wissam's and Teta Loubia's stories show the complexity of their experiences of loss, despite belonging to different generations of Palestinian women. Both women are daughters, mothers, and grandmothers. They now live in separation from their mothers and grandchildren, and both have lost family members whose final resting place is in Syria. Yet, the two women speak of Syria in different ways. For Teta Loubia, who belongs to the first Generation, namely that of the Nakba, Syria is a temporary home and her first place of refuge as an infant. She recalls Palestine as her mother's home and her own place of connection.

"To be able to return to Palestine is a dream. Palestine is my home country; it's where my mother and father were born. I was still in my mother's womb when she left Palestine. But now that both my parents, my husband, and my grandson, are buried in Syria, home can only be where their final resting place is."

In the present, the loss of her beloved eclipses the loss of Palestine, and somehow makes what was lost in Palestine and what was lost in Syria merge in a single narrative of home; a home that is neither Palestine, nor Syria. "I mean, my grandchildren might one day be able to see Haifa if they are granted European passports [inshallah], but we will never return to Syria. Syria is lost, and for me Palestine is also lost," said Teta Loubia.

Amal Wissam, who belongs to the second generation of Palestinian women (the generation of the Revolution), views Syria as her real home, and Denmark as a "safe house." When she spoke of Palestine, she recalled her grandfather's narratives of the country, and of Jaffa in particular. The coast in her own narrative holds a symbolic value and is a very physical element that shows the simultaneous connection and disconnection.

"If I had been born in Palestine like my parents and grandparents, I would have known the sea of Jaffa. We call it 'arūs al sahil [The bride of the coast]. Ever since I was a little girl, my father would talk about Palestine and how he used to play on the beach... because we had never seen the sea. He told me he used to play along the beach, but also in the sea. He knew it by heart. [...] I grew up never knowing Palestine, but I have told my children about Jaffa, the same way I had learned about it from my own father. [...] In Syria, we had a place to call our home. We built a life for ourselves there. I still dream of being able to return to Palestine, but I don't think

\footnotetext{
${ }^{64} \mathrm{Ibid}$.

${ }^{65}$ Oral History Recording with Teta Loubia, March 2018.

${ }^{66}$ Oral History Recording with Teta Loubia, March 2018.
} 
I'll be able to or even have the right to in my lifetime." ${ }^{67}$

There is a stark difference when it comes to the narrative of return to Palestine among the generation of women born between 1985 and 1995 (The Pharmacist) and those born between 1995 and 2000 (Jescala Al-Homisa). For women belonging to the third generation, such as in the case of The Pharmacist, anger and frustration prevail over the failed revolutions and the ongoing war. Women of the fourth generation, such as Jescala Al-Homsia, seem to be hopeful that a brighter future awaits them, and that returning to Palestine will be feasible through the persistent demand of the right of return and citizenship, political participation, education, and being granted passports in European countries. "Europe is the door leading to Palestine. Though it would take less than an hour to drive from Damascus to Palestine, the road to Palestine today goes through Europe." however, differences within each generation dictate how past events and the current place of residence colour and contour these women's views of the future.

\section{Hope and hopelessness: Divergence and Convergence between the Two Youngest Generations}

This section presents the narratives of two women belonging to the two youngest generations of Palestinians. They are both single, have no children, and grew up in different parts of Syria. The first woman was born in 1986, and educated as a pharmacist in Syria. She belongs to the third generation of Palestinians, which she called "the Generation which fuelled the Uprisings and lost Syria." The name matches the one attributed to this generation by public participant Hady Ibrahim from the Palestinian Refugees Portal. ${ }^{69}$ The second woman is Jescala al-Homsi, who belongs to the fourth and youngest generation of Palestinians. She called her generation "the Generation of the Struggle and the Return... to Palestine." The ways in which the women belonging to these two generations diverge and converge are compelling because they have both undergone crucial personal developments since 2011, albeit in different directions: the first through political activism and the second through education in exile. Their lives are shaped by the milieu that they inhabit, and the destruction of their former communities.

The Pharmacist, ${ }^{70}$ the only participant in this study who remains in Syria, has a significantly different narrative from the three other women. There is a difference between remaining in the warzone and the experiences of escape, resettlement, and integration into a new society, away from war. In the literature, few scholars have engaged with women who remain in Syria, due to their inability to travel to Syria and the risk of deterrents. Author Samar Yazbek's novels and nonfiction work resonate with women's narratives from Syria. ${ }^{71}$ Some of Yazbek's narratives resemble the Pharmacist's. The Pharmacist calls Syria a "country of war." Her activism prompted her to stay in Syria even when the borders were still open, and

\footnotetext{
${ }^{67}$ Oral History Recording with Teta Loubia, February 2018.

${ }^{68}$ Oral History recording \#2 Jescala Al-Homsia, August 2019.

${ }^{69}$ Interview with Hady Ibrahim, April 2018; Palestinian Refugees Portal, Website, Palestinian Refugees Portal, available at: http://palref.com/. [Last accessed on 27 February 2020]

${ }^{70}$ The Pharmacist is the participant's self-chosen pseudonym. To learn more about the challenges connected to anonymity and representation in small communities. See: Dheeba Moosa, "Challenges to anonymity and representation in educational qualitative research in a small community: a reflection on my research journey," Compare: A Journal of Comparative and International Education, 2013, Vol. 43(4), p. 483-495.

${ }^{71}$ Women Now for Development, Website, Women Now for Development, available at: https://women-now.org/[Last accessed on 27 February 2020]; Samar Yazbek, Al-Mashā'a [The Walker], Beirut, Dar Al-adab Al-Aula, 2017; Samar Yazbek, 19 imra'a: souriyyat yarwayn [19 women: Tales of resilience from Syria], Milano, Manshurat al Mutawassit, 2018.
} 
though she had hoped to leave, she told me that doing so was no longer an option for her, since she was so politically involved. As a medical professional, she felt that she had a crucial role to play in her community. The shortage in medication for the treatment of war injuries and other health issues is tremendous, and she has spent years creating a women-led network of pharmacists who can provide access to medications for elders, new-born children, pregnant women, mothers, and disabled people.

The Pharmacist went from being a religious graduate student about to get married, to becoming a revolutionary feminist within eight years. She said that women have been very present on the field in Syria, fighting the forces of the regime, $D \bar{a}$ ish, and other Islamist rebels and male revolutionaries who do not wish to empower their female counterparts in the patriarchal society. She remains hopeful that the regime will fall; for her, "a Syria for all free Syrians" is the future. She has been evacuated to different locations over ten times in the past five years. She named her generation "the Generation that Fuelled the Uprisings and Lost Syria," and described the social structures and the role they played in the failure of the popular uprisings. She sees how the world and the regime are silencing women in Syria. For her, being Palestinian in war-torn Syria is at once a major issue and yet it seems to be less pertinent than than her daily struggles with the Syrian regime. She emphasises the solidarity between the different ethnic and religious groups in Syria, as they all share a common goal: freedom from oppression. She has witnessed Palestinians being rejected after standing in line for hours, waiting for aid supply (the aid kartone [box] distributed by UNRWA), or medical care. She has seen the Palestinian communities in Syria living under siege and being treated like fugitives. She expressed concern over Palestinian children's lack of access to education and proper health care and fears that the next generation will be unable to stand up to oppressive forces due to the lack of education and poverty. The Pharmacist cannot access her home or see her siblings and parents, because of military checkpoints surrounding the area and the need for permits from the regime. She avoids checkpoints in fear of persecution. The Pharmacist explained that "the Syria that we [the Palestinian communities] had is lost." There is an urgent need for rebuilding the Palestinian communities in Syria, so that both Syrian and Palestinian communities can flourish again.

Jescala Al-Homsia, ${ }^{72}$ who belongs to the fourth generation of Palestinian women, lives near Copenhagen. When we first met in 2018, Jescala was 22 years old. She had just finished her first term at the University of Copenhagen. She arrived with her father in Denmark in 2014. Jescala's family is from the village of Al-Jish in northern Palestine. The village was occupied on 29 October 1948 and has been under Israeli occupation since. Jescala's grandparents escaped to Lebanon, travelled to Syria by train, and re-settled in Al-Aidin camp in the Syrian city of Homs. ${ }^{73}$ Before fleeing Syria, Jescala had witnessed siege, shelling, and massive destruction. She said that an entire generation of young people were either killed or had left Al-Aidin camp. Jescala thought that it was very important to hold on to Syria the way she remembered it - the same Syria she would want her future children to know about:

"If my children should know anything about Syria, I wouldn't want them to be bombarded with stories about the war. [...] I want to share with them the pleasant memories I have about that place; the way we lived together, and what our lives were like in Syria. [...] I want to tell them about what the schools were like, and how the school system

\footnotetext{
72 Jescala Al-Homsia is a self-chosen pseudonym. Jescala is the female version of the noun and village name Al-Jish. Al-Homsia (female adjective) is the female adjective derived from the noun Homs; it means "woman hailing from Homs." ${ }^{73}$ The city of Homs was severely bombarded since 2013. See: Action Group for Palestinians of Syria, "Shelling Targets Al-Aedein Camping Homs and Khan Al Shieh in Damascus Suburb and Clashes Continue in Yarmouk", London, Action Group for Palestinians of Syria, 8 June 2015, available at: http://actionpal.co.uk/en/reports/daily/08-6-2015.pdf [last accessed on 27 February 2020].
} 
was, because it's very different from the way it is here. [...]. Especially for me as a muhajaba (veiled woman) [...] to me that was like freedom, because I used to go to an all-girls' school in Syria, and many other students wear the veil. [...] At my old school, there were many festivals that focused on Palestinian heritage, the Palestinian time [zamān filasțīn], Palestinian dances, like dabka, it was really beautiful. [...] We took classes that focused on several topics relating to Palestine; we would make dresses and learn embroidery, or study Palestinian history... things like that. But that is lost now. [Deep sigh]." ${ }^{74}$

In the quote above, Jescala is talking about Homs, the city she is from in Syria, and how it gave her and her schoolmates a way to remember and learn about Palestine. The quote also shows how Jecsala connects these memories to her new life in Denmark, and how different life is there. At the same time, it is clear that she does not wish for the next generation to become familiar with her own experiences and memories of the war. Like Amal Wissam and Teta Loubia, it was difficult for Jescala to talk about the war in Syria, often avoiding the topic altogether. However, when speaking about her childhood memories she explained that she had gotten access to a part of her life that she had left behind. Knowing that war and armed conflict exist and can be part of life is one thing, and experiencing war, especially on a sensorial level, is another: its smells, sounds, and sights. As Jescala fittingly says: "I will never forget [the war], and at the same time I don't want to remember it. So it's actually nice to remember the camp in which we lived and the school I used to go to as a child - and my old teachers; I wonder where they are now. No one has asked me these questions before." ${ }^{\text {" }}$ The loss that Jescala describes echoes through the four generations. But Jescala's narrative bears more hope, and she believes that her education and volunteering as a medical professional in an NGO can help her travel to Palestine.

"I left Syria as a girl. Now, I am a woman, and I have to provide for my parents and siblings. Education is my only weapon against further oppression as a stateless Palestinian. [...] I remember that my Jeddoh (grandfather) in Syria once said to me: 'Let education be your weapon, and that will be your resistance [muqāwama] to oppression.' [...] So, when we were young, we thought that we could contribute to Palestine's growth through education." 76

The two young women in this section have different views of the future. While Jescala sees hope in education and has no wish to be politically active, The Pharmacist is wary of the next generation's lack of access to education and fears that it will affect the Palestinian community in Syria. For her, political activism is the only way to free Syria and to ultimately return to Palestine. Despite the discrimination that Palestinians are subjected to in Syria, the loss of Syria is for the participants perceived as catastrophic, and bears both emotional and practical consequences on the Palestinian community, as this paper has shown.

\section{Conclusion}

Based on women's oral history, this paper presented glimpses of transgenerational narratives of Palestinian women born in Syria. By including women from four different areas and generations in this study, it becomes clear that there is no single category of "Palestinian women from Syria" that fits all women. The women talk about the lives of the people in their communities, families, children, fathers, husbands, other women, and about their own

\footnotetext{
${ }^{74}$ Oral History Recording \#1 Jecala Al-Homisa, Copenhagen, 16 February 2018.

${ }^{75} \mathrm{Ibid}$.

${ }^{76}$ Ibid.
} 
struggles and endeavours. This paper has shown that the literature on the socio-historical experiences of Palestinian women residing in Syria since 1948 is limited, and that these narratives should be uncovered in order to gain a better understanding of global systems of oppression and to argue for change. It also argues that the structural discriminative settings created over the past 138 years still affect Palestinians from Syria today, whether they currently reside in Syria, Europe, or elsewhere; being both a stateless refugee and a woman has engendered structural oppressive continuities across more than four generations. Twelve constraints in total have been identified by the women. The participants of the oral history project helped to fill some of the knowledge gaps as they countered misrepresentations, recounted several of their experiences. Their narratives all together emphasise their strengths and their active presence in this world, in opposition to what is often seen as a forgotten past.

The results of the research show that experiences of loss crosscut generations. There are diverse experiences of the present across the four generations, including both new avenues of opportunity for the women and several kinds and combinations of loss e.g. loss of identity, family members, job loss, loss of free movement, and loss of Syria as a safe home. The loss of Syria reveals the prolonged temporariness of the participants' statelessness. It also reminds the younger generations of the differences between what they have had to live through today, and what their grandparents lived through before, during and immediately after 1948. I argue that it is only through listening to the experiences of these groups of women, that we can begin to learn more about the past. By taking the responsibility of listening and knowing, researchers can gain insight into the plight of the stateless Palestinian women in Syria, who have been displaced within Syria, or relocated to Europe. As oral historian and anthropologist Rosemary Sayigh writes: "It is in this battleground that we need to situate these Palestinian women's narratives, and ourselves as listeners: first as challenging the silencing of Palestinian history, second as challenging colonialist constructions of Arab/Muslim women that are part of a larger enterprise to dominate and exclude; and third, as challenging a social structure and attitude that would limit their speech and agency."77

The women in this project are compelled to navigate between East and West, Europe and West Asia, European languages and Arabic. Social-nationalistic, settler colonial, and totalitarian state efforts deny them the right to return to their homeland, while also prohibiting them from fully belonging in their new host communities. The experiences and histories of Palestinian women born in Syria are hence both local and global. The women uphold that despite being discriminated against in Syria, the country must also be understood as a real and good home, in contrast to a temporary safe space that they inhabit. What was lost, must not be reduced to a discourse of "good versus evil." The women who participated in this study lost their former homes, the graves of their loved ones, their lives, communities, and founding years. The important task that lies ahead is to avoid demonising these communities, while highlighting that these women experience new and aggravated kinds of oppression in Europe, in the form of islamophobia and xenophobia, among others. The oral histories collected here are narrated by stateless refugee women who have been separated from their families and homeland under the current-day war, asylum, and refugee regimes. It is crucial to notice how in the midst of loss, these women insist on their right to return to Palestine, while arguing for the right to fully belong in their host country. In order to reach real social change, we need to listen to these narratives as reasonable political demands.

\footnotetext{
${ }^{77}$ Rosemary Sayigh, op.cit., 2007, p.154.
} 


\section{Acknowledgements}

I would like to extend my gratitude to all the participants and their families, as well as to my co-panellists from the panel "Lebanon, Syria, and Palestine: Colonial Histories between a Durable Presence and Present" at the University of Vienna, 20 May 2019; Dr. Helene Kazan, Dr. Adriana Qubaia, Noura Salah Aldeen, and Klaudia Rottenschlager. The PhD research is funded by the University of Leicester.

\section{Bibliography}

Nahla Abdo, Women in Israel Race, Gender and Citizenship, London, Zed Books Ltd, 2011.

Nahla Abdo and Nur Masalha, An Oral History of the Palestinian Nakba, London, Zed Books Ltd, 2018.

Lynn Abrams, Oral History Theory, New York, Routledge, 2010.

Nour Abu-Abbas and Nuf Nasser-Eddin, "(Re)-Centralising Palestine in Decolonial Feminist Theory," Kohl: A Journal for Body and Gender Research, 2019, Vol. 5(1), p.6-10.

Maya Abyad, "Imprisoned By The Regime, And Ostracised By Society. Consequences of detention for Syrian women," Website, Syria Untold, 2019, available at:

https://syriauntold.com/2019/10/o7/imprisoned-by-the-regime-and-ostracised-by-society/ ?fbclid=IwAR03V5qI mEWQ4TpsTsiKWXOEsGiQTpfi3tsDRNH7hFaUMs4y9Sp AcNg A [last accessed 27 February 2020]

Action Group for Palestinians of Syria and The Palestinian Return Centre, "Palestinians of Syria and the Closed Doors", London, Action Group for Palestinians of Syria and The Palestinian Return Centre, 2017, available at: https://www.actionpal.org.uk/en/pdf/closeddoor2016.pdf [last accessed on 27 February 2020]

Action Group for Palestinians of Syria, "Shelling Targets Al-Aedein Camping Homs and Khan Al Shieh in Damascus Suburb and Clashes Continue in Yarmouk", london, Action Group for Palestinians of Syria, 8 June 2015, available at:

http://actionpal.co.uk/en/reports/daily/08-6-2015.pdf [last accessed on 27 February 2020]

Nadje Al-Ali, Secularism, Gender \& the State in the Middle East: The Egyptian Women's Movement, Cambridge, Cambridge University Press, 2000.

Susan M. Akram,"Myths and Realities of the Palestinian Refugee Problem: Reframing the Right of Return” In Michael Lynk, Michael Dumper, Susan Akram, Iain Scobbie (eds.), International Law and the Israeli-Palestinian Conflict. A Right-Based Approach to Middle East Peace, New York, Routledge, 2011, p.183-198.

Anaheed Al-Hardan, "Remembering the Catastrophe: Uprooted Histories and the Grandchildren of the Nakba," PhD Dissertation, Dublin, University of Dublin, 2011.

Anaheed Al-Hardan, "Decolonizing Research on Palestinians: Towards Critical Epistemologies and Research Practices," Qualitative Inquiry, 2013, Vol. 20(1), p.61-71. 
Anaheed Al-Hardan, Palestinians in Syria: Nakba Memories of Shattered Communities, Columbia, Columbia University Press, 2016.

Noura Alkhalili,"Between Sumud and Submisison: Palestinian Popular Practices on the Land in the Edge Areas of Jerusalem," PhD Dissertation, Lund, Lund University Publications, 2017, p.1-188.

Hamad Said Al-Mawed, The Palestinian Refugees In Syria Their Past, Present and Future, Ottawa, International Development Research Centre, 1999.

Susan H. Armitage, “The Stages of Women's Oral History,” In Donald A. Ritchie (eds.), The Oxford Handbook of Oral History, Oxford, Oxford University Press, 2012, p.169-185.

Nidal Bitari, "Yarmuk Refugee Camp and the Syrian Uprising," Journal of Palestine Studies, 2014, Vol. 43(1), p. 61-78.

Laurie A. Brand "Palestinians in Syria. Politics of Integration," The Middle East Journal, 1988, Vol. 42(4), p.621-637.

Joseph Daher, "Palestine: "No Liberation Without Free Women," Website, Europe Solidaire, 14 October 2019, available at:

http://www.europe-solidaire.org/spip.php?article50870[Last accessed on 27 February 2020]

Janelle L. Dance, Mary Hermes and Gutierrez Rochelle, "More Like Jazz Than Classical: Reciprocal Interactions Among Researchers and Respondents," Harvard Education Review, 2010, Vol. 80(3), p. 327-352.

Veena Das, “The Act of Witnessing: Violence, Poisonous Knowledge, and Subjectivity” In Mamphela Ramphele, Arthur Kleinman, Pamela Reynolds, and Veena Das (eds.), Violence and Subjectivity, Berkeley, University of California Press, 2000, p.215-225.

Didier Fassin and Richard Recthman, The Empire of Trauma: An Inquiry into the Condition of Victimhood, New Jersey, Princeton University Press, 2009.

Susanna Ferguson,"Listening to Rights Talk in Damascus," Comparative Studies of South Asia, Africa and the Middle East, 2015, Vol. 35(3), p. 557-574.

Ellen L. Fleischmann, The Nation and Its "New" Women. The Palestinian Women's Movement 1920-1948, Los Angeles, University of California Press, 2003.

Michael Frisch, A Shared Authority. Essays on Craft and Meaning of Oral and Public History, New York, State University of New York Press, 1990.

Nell Gabiam, The Politics of Suffering: Syria's Palestinian Refugee Camps, 
Bloomington, Indiana University Press, 2016.

Sherna Gluck, "What's so Special about Women? Women's Oral History.” Frontiers:A Journal of Women Studies, 1977, Vol. 2(2), p.3-17.

Ronald J. Grele and Studs Terkel, Envelopes of Sound: The Art of Oral History, London, Praeger, 1991.

Ghassan Hage, “Towards a Critical Arab Social Science,” Website, Critical Legal Thinking, 8 April 2013, available at:

http://criticallegalthinking.com/2013/04/08/towards-a-critical-arab-social-science/. [Last accessed on 27 February 2020]

Salah Hassan, "Palestinians in Syria and the Syrian Uprising," Doha, Arab Center for Research and Policy Studies, 11 October 2012, available at:

https://www.dohainstitute.org/en/lists/ACRPS-PDFDocumentLibrary/Palestinians in Syri a and the Syrian Uprising.pdf [last accessed 27 February 2020]

Bell Hooks, "CHOOSING THE MARGIN AS A SPACE OF RADICAL OPENNESS." Framework: The Journal Of Cinema and Media, 1989, Vol.36, p.15-23.

Institute on Statelessness and Inclusion, "World Conference on Statelessness," The Hague, Institute on Statelessness and Inclusion, 2019, available at:

https://www.institutesi.org/conference [Last accessed on 27 February 2020]

Islah Jad, "Rereading the British Mandate in Palestine: Gender and the Urban Rural Divide in Education,” International Journal of Middle East Studies, 2007, Vol. 39, p. 338-42.

Suad Joseph, Gender and Citizenship in Middle Eastern States, New York, Syracuse University, 2000.

Anja Kublitz, "From Revolutionaries to Muslims: Liminal Becomings Across Palestinian Generations in Denmark," International Journal of Middle East Studies, 2016, Vol. 1, p. 67-86.

Mette Heide-Jørgensen Lundsfryd, "Speaking Back to a World of Checkpoints: Oral History as a Decolonizing Tool in the Study of Palestinian Refugees from Syria in Lebanon," Middle East Journal of Refugee Studies, 2017, Vol. 2(1), p.73-95.

Rania Maktabi, “Gender, Family law and Citizenship in Syria,” Citizenship Studies, 2010, Vol. 14(5), p. 557-572.

Nur Masalha, Expulsion of the Palestinians. The concept of Transfer in Zionist Political Thought, 1882-1948, Beirut, Institute for Palestine Studies, 1992.

Nur Masalha, The Palestine Nakba: Decolonising History, Narrating the Subaltern, Reclaiming Memory, London, Zed Books Ltd, 2012.

Kristina Minister "A Feminist Frame for the Oral History Interview," In Sherna B. Gluck and Daphne Patai (eds.), Women's Words, New York, Routledge, 1991, p. 27-42. 
Annelies Moors, "On Appearance and Disappearance. Representing Women in Palestine under the British Mandate,” Thamyris, 1996, Vol. 3(2), p.279-310.

Nina Murray, "Join the feminist revolution in work to address statelessness," Website, European Network on Statelessness, 18 July 2019, available at: https://www.statelessness.eu/blog/join-feminist-revolution-work-address-statelessness [Last accessed on 22 November 2020]

Dheeba Moosa, "Challenges to anonymity and representation in educational qualitative research in a small community: a reflection on my research journey," Compare: $A$ Journal of Comparative and International Education, 2013, Vol. 43(4), p. 483-495.

Nafez Nassal, The Palestinian Exodus from Galilee, 1948, Beirut, Institute for Palestine Studies, 1978.

Palestinian Refugees Portal, Website, Palestinian Refugees Portal, available at: http://palref.com/. [Last accessed on 27 February 2020]

Julie Peteet, Landscape of Hope and Despair: Palestinian Refugee Camps, Philadelphia, University of Pennsylvania Press, 2005.

Ahmed Sa'di and Lila Abu-Lughod, NAKBA: Palestine, 1948, and the Claims of Memory, New York, Columbia University Press, 2007.

Ruba Salih, "Bodies That Walk, Bodies That Talk, Bodies That Love: Palestinian Women Refugees, Affectivity, and the Politics of the Ordinary," Antipode, 2016, Vol. 49, p.742- 760 .

Rosemary Sayigh, Palestinians: From Peasants to Revolutionaries, London, Zed Books Ltd, 1979.

Rosemary Sayigh, Too Many Enemies. The Palestinian Experience in Lebanon, London, Zed Books Ltd, 1994.

Rosemary Sayigh, "Palestinian Camp Women as Tellers of History,"Journal of Palestine Studies, 1998, Vol. 27(2), p. 42-58.

Rosemary Sayigh, "Women's Nakba Stories: Between Being and Knowing, ” In Ahmed Sa'di and Lila Abu-Lughod (eds.), Nakba: Palestine, 1948, and Claims of Memory, New York, Columbia University Press, 2007, p. 135-160.

Rosemary Sayigh, "The Nakba's Exclusion from the "Trauma Genre", Journal of Palestine Studies, 2013, Vol. 43(1), p. 51-60.

Rosemary Sayigh, "Nakba Silencing and the Challenge of Palestinian Oral History," In Nahla Abdo and Nur Masalha (eds.), An Oral History of the Palestinian Nakba, London, Zed Books, 2018, p.114-135.

Buthaina Shaheen, "Yarmouk Minors: Their Situation and Displacement... Their 
Agency through Cultural Forms, Psychosocial Activities and through Daily Life Actions," British Journal of Middle Eastern Studies, November 2018, p.1-16.

Buthaina Shaheen, "Ambivalences of Citizenship: Syrians with Refugee Status Responding to Ambivalences of Citizenship in Denmark,"Journal of Refugee Studies, 2020, fez107.

Nadera Shalhoub-Kevorkian, "Palestinian Women and the Politics of Invisibility: Towards a Feminist Methodology," Peace Prints: South Asian Journal of Peace building, 2010, Vol. 3(1), p.1-21.

Åge A. Tiltnes, "Palestinian Refugees in Syria: Human Capital, Economic Resources and Living Conditions", Borggata, FAFO, 2006, available at:

https://www.fafo.no/index.php/en/publications/fafo-reports/item/palestinian-refugees-insyria-human-capital-esconomic-resources-and-living-conditions [Last accessed on 27 February 2020].

Anne Valke and Leslie Brown, Leslie Living with Jim Crow: African American Women and Memories of the Segregated South, New York, Palgrave Macmillan, 2010.

Anne Valk et al., "Engaging Communities and Classrooms: Lessons from the Fox Point Oral History Project," The Oral History Review, 2011, Vol. 38 (1), p. 136-57.

Lorenzo Veracini, Settler Colonialism: A Theoretical Overview, Hampshire, Palgrave Macmillan, 2010

Women Now for Development, Website, Women Now for Development, available at: https://women-now.org/[Last accessed on 27 February 2020].

Samar Yazbek, Al-Mashā 'a [The Walker], Beirut, Dar Al-adab Al-Aula, 2017.

Samar Yazbek, 19 imra'a: souriyyat yarwayn [19 women: Tales of resilience from Syria], Milano, Manshurat al Mutawassit, 2018.

Elise G. Young, Keepers of the History: Women and the Israeli Palestinian Conflict, New York, Teachers College Press, 1992.

Elise G. Young, "From Data to Doctor. Health, Gender, and the Race for Control of Knowledge-Making in Mandatory Palestine," Thamyris, 1997, Vol. 4 (2), p.347-58.

Elise G. Young, Gender and Nation Building in the Middle East: The Political Economy of Health from Mandate Palestine to Refugee Camps in Jordan, London, Bloomsbury Academic, 2012.

Nira Yuval-Davis, Gender and Nation, London, Sage Publishing, 1993.

Nira Yuval-Davis, "Women and the Biological Reproduction of "the nation", Women's Studies International Forum, 1996, Vol. 19(1-2), p. 17-24.

Rafeef Ziadah, “Journeys of Dispossession: Palestinian Refugees from Syria 
Confronting Fortress Europe, "Website, Darkmatter, 2016, available at:

http://www.darkmatter101.org/site/2016/05/16/journeys-of-dispossession-palestinian-refu gees-from-syria-confronting-fortress-europe/. [Last accessed on 27 February 2020]. 